\title{
Recovering Islands: Scotland, Ocean, and Archipelago in To the Lighthouse
}

Nels C. Pearson

Fairfield University, npearson@fairfield.edu

Follow this and additional works at: https://digitalcommons.fairfield.edu/english-facultypubs Copyright (c) 2018 Hofstra University

The author post-print has been archived here with permission from the copyright holder.

Final publisher version available here: https://read.dukeupress.edu/twentieth-century-lit/articleabstract/64/3/347/135303

\section{Peer Reviewed}

\section{Repository Citation}

Pearson, Nels C., "Recovering Islands: Scotland, Ocean, and Archipelago in To the Lighthouse" (2018).

English Faculty Publications. 139.

https://digitalcommons.fairfield.edu/english-facultypubs/139

\section{Published Citation}

Pearson, Nels. "Recovering Islands: Scotland, Ocean, and Archipelago in To the Lighthouse." Twentieth Century Literature 64.3 (2018): 347-370. https://doi.org/10.1215/0041462X-7142083

This item has been accepted for inclusion in DigitalCommons@Fairfield by an authorized administrator of DigitalCommons@Fairfield. It is brought to you by DigitalCommons@Fairfield with permission from the rightsholder(s) and is protected by copyright and/or related rights. You are free to use this item in any way that is permitted by the copyright and related rights legislation that applies to your use. For other uses, you need to obtain permission from the rights-holder(s) directly, unless additional rights are indicated by a Creative Commons license in the record and/or on the work itself. For more information, please contact digitalcommons@fairfield.edu. 
Nels Pearson

Fairfield University

Final Submitted Version

Twentieth Century Literature 64.3 (2018): 347-370

Recovering Islands: Scotland, Ocean and Archipelago in To the Lighthouse

"One can hardly tell which is the sea and which is the land," said Prue

-Virginia Woolf, To the Lighthouse

Among the significant effects, or by products, of Anglophone postcolonial theory and cultural study is that it has compelled English society to reflect critically upon its own constructions of race, nation, and modernity. More recently, this self-critique has been bolstered by interrogations of the cultural-geographic abstractions that comprise the traditional "island nation" image of Great Britain and the related notion of the organic relationship between this national geography and imperial expansion via the sea. Reinforced by U.K. devolution, this new British historiography is exemplified in J.G.A. Pocock's “present[ation of] 'British history' as archipelagic rather than English," wherein the term "archipelagic" is used "to remind ourselves . .. that we are writing a history pelagic, maritime and oceanic, into which an extraordinary diversity of cultural and other movements has penetrated deeply" (2005, 78). In literary history, this approach is represented by John Kerrigan's call "to strip away modern Anglocentric and Victorian imperial paradigms to recover the long, braided histories played out across the BritishIrish archipelago" $(2008,2)$.

Such archipelagic models have resulted in our seeing Scottish, Welsh, Manx and Cornish populations, and their associated peninsulas, coasts and islands, less as peripheral sites of archaic, romanticized, or inherently distinct sub-cultures within a centripetal, Anglocentric 
Britishness and more as examples of an interactive history of diverse cultures played out across a shared island ecology and maritime economy. The move in Irish studies towards less binary, more culturally varied and transnational approaches to the relationship between England, Ireland, and the oceanic empire has only redoubled this new understanding. ${ }^{1}$ As a result, and despite Brexit, we are learning to think about the "British Isles" as a North Atlantic archipelago across which notions of Britishness and Englishness have been in near constant flux, contingent upon constructions of the "Celtic fringe" that belie the complexity and diversity of interrelationships among Scotland, Ireland, England, Wales, and Cornwall, as well as the migrations woven into each (Kerrigan 2008, 11-12).

These studies shed significant light on Virginia Woolf's To the Lighthouse—and, in particular, its use of the Scottish Hebrides as a setting — in ways that have not been sufficiently recognized. With its setting in the Hebrides near the Northwest extremity of Great Britain, its evocation of the Stephens' summer home in Cornwall, at the Southwest extremity of Great Britain, its imagery of sea, coasts, and islands, and its pervasive motif of entities drifting apart and reassembling, To the Lighthouse profoundly evokes the archipelagic reality of the AngloCeltic Isles. And yet, only a handful of critics have considered the political or historical significance of the novel's setting at any length. Those who have done so, most notably Jane Goldman, have pointed out that the Scottish allusions and contexts are in fact quite substantial, and that they are integral to the novel's interrogation of patriarchal and imperial ideologies. ${ }^{2}$ Meanwhile, expressly postcolonial readings of To the Lighthouse have either overlooked the Scottish setting or have interpreted it as part of a modernist subversion of dominant nationalistic or imperial paradigms. ${ }^{3}$ In what follows, I hope to offer a more comprehensive, archipelagic reading of the novel—one that explores how it both interrogates and participates in problematic 
cultural and geographic constructs of Britishness, especially as these were manifest in a United Kingdom that had recently seen most of the Irish island violently separated into a Free State.

To properly situate To the Lighthouse in an archipelagic context, it is helpful to review some of the basic history linking England, Scotland, and the British empire—-history whose literary dimensions, and broader thematic significance, Woolf would have taken for granted. After Scotland lost its independence to England in 1707, thereby "inventing" the Kingdom and "would-be nation" of Great Britain (Colley 2005, 11), many of its regions underwent an industrial boom fueled by their involvement in the British maritime empire. Scotland is thus indissolubly linked with empire and the concept of Britishness, first as an internal, contiguous colony differentiated by class, language and social formations rather than race, and, soon thereafter, as a collaborator in imperial practices, migrations, and markets. Even as many Scottish institutions and rural populations were eroded under England's imperial control and the concomitant surge of capitalism, so too did many Scots find it expedient to serve as agents of empire, participating heavily in British settler migrations; imperial trade related to American tobacco, Asian tea and opium, and Caribbean sugar and rum; and the slave economy. T.M. Devine (2003) has extensively chronicled this interdependence of Scottish labor, capital and overseas imperialism in his recent study Scotland's Empire 1600-1815. Especially when it is employed abstractly by an artist associated with the metropolitan core, Scotland also brings to mind the notorious vagueness and "pluralist semantics" of the term "British" as a cultural or ethnographic marker (Pocock 2005, 37) —specifically its denotation of a modern, economically expedient union between England and Scotland using nebulous connotations of ancient Anglian society and a presumably common racial vocation to "rule the waves" (Pocock 2005, 37; Colley 2005 11-14). 
Hence, as Woolf was no doubt aware, outer Scotland evokes the origins and the fragility of "Britishness" as well as its inherent ties to imperial expansion and oceanic dominion. The Scottish islands, in particular, also encourage readers to reflect on the cultural and geographic perimeter, or extreme limit, of Great Britain. Like Wales and Cornwall, but in more pronounced ways, Scotland and its diffuse, Celtic-Norse islands are thus reminders that Britishness and Great Britain, for all their effective power, are thin constructs—concepts that begin with appropriations and amalgamations and are hence always subject to dissolution and fragmentation. A map of the Hebrides - such as the one Lily Briscoe examines as she contemplates whether art can unify diverse entities (Woolf 1989, 113)—reminds us that the islands themselves represent this fragile contingency, insofar as they physically embody the twin notions of assembly and dispersal. ${ }^{4}$

The timing of To the Lighthouse, which Woolf composed between August 1925 and March 1927, is also significant from an archipelagic standpoint. ${ }^{5}$ For the middle 1920 's were marked by a concern for the size, shape, and nature of the Britain and United Kingdom that were to remain in a post-war age that had also now seen the partition of Ireland after the violent Anglo-Irish War (1919-1921) and Irish Civil War (1922-1923). Throughout the early- to mid1920 's, the isles witness a trend of what could be called "little Britainism," whereby it became easier to imagine the United Kingdom (now made up of Scotland, England, and Northern Ireland) as culturally "British," a concept that itself became more English. As Kerrigan notes in Archipelagic English, "the remapping of Irish culture [caused a] setback to imperial unionism [that] both reinforced 'little Englandism' and ... made it easier to think of 'Britain' as England writ large" (2008, 4-5). The 1920's are also crucial, he adds, "because the publication of 'The Newbolt Report' in [1921] is conventionally identified as the start of modern, institutionalized English [language and literature curricula]" $(2008,4)$. Kerrigan reads the Newbolt Report as a 
reactionary Anglicizing of archipelagic literatures - a counter to Gaelic and Celtic nationalist movements that began with the 1901 edition of Robert Chambers' Cyclopaedia of English Literature, which had "advanced [arguments] for regarding Scottish Highland and Irish culture as 'English' [that were] implausibly, racially unionist' $(2008,4)$.

More than just an intellectual matter, these curricular reactions to emergent Scottish, Irish, Welsh and Manx language movements were instrumental in the construction of the isles as an Anglocentric British state. "Celtic" vernacular literatures had become a respectable subject of academic study around the turn of the century, thanks to French and German Celticists and, in the isles, to Matthew Arnold, who had promoted their study against the reigning, philistine disdain for anything that mitigated the pan-insular dominance of the English language. However, the merit and impact of those literatures were limited to the manner in which they expressed spiritual, pre-modern sensibilities that could help temper the more industrial and civic English mind. Writes Arnold,

It is not in the outward and visible world of material life that the Celtic genius of Wales or Ireland can at this day hope to count for much; it is in the inward world of thought and science. [Let us not] attend ... to what it will be or will do, as a matter of modern politics. It cannot count appreciably now as a material power; but, perhaps, if it can get itself thoroughly known as an object of science, it may count for a good deal, far more than we Saxons, most of us, imagine, as a spiritual power. $(1883,12)$

This association of Celticism with a transcendent and hence anti-materialist culture, an idea borrowed by Abbey Theatre revivalists and to an extent by Hugh MacDiarmid and the Scottish Renaissance, initiates a self-fulfilling binary. For one of its effects is that Celtic traditions, even as they are being included on the cultural map of the British Isles, are simultaneously being 
contained as the source of a "spirituality"- what Arnold elsewhere calls "the Titanism of the Celt, his passionate, turbulent, indomitable reaction against the despotism of fact" $(1883,118)$ that precedes the pragmatic reason now essential to statecraft and material, capitalist progress. At best, "as an object of science," the Celtic element can be utilized to make these Saxon priorities more humane. The romanticized or mythologized Celt is thus left outside the pale of progress: included within a vaguely Britannic space, yet removed from the map of the actively historical, trans-insular state. ${ }^{6}$

On its surface, or in its plot and characters, To the Lighthouse only briefly engages these concerns over Britishness, Scotland, and the Celtic fringe. One of the ways it does so is through the family surname, Ramsay, which suggests that Mr. Ramsay or one of his progenitors is of Scottish birth or extraction. Such a connection was of course widely shared across English families (including, by her claim, Woolf's own ${ }^{7}$ ), and its likelihood in Mr. Ramsay's case is further implied when Mrs. Ramsay contrasts her genteel Italian heritage to "the sluggish English, or the cold Scotch" bloodlines that she apparently aligns with her husband (Woolf 1989, 9). Mr. Ramsay is also invested in Enlightenment empiricism and Thomas Carlyle, icons of the Scottish contribution to the rationalist humanism that drove the imperial and political identity of Great Britain. As Jane Goldman has noted, Woolf thematically connects Mr. Ramsay, whose intellectual energy is restored as he reads Sir Walter Scott's The Antiquary, to "John Ramsay (1736-1814) of Ochtertyre, Stirling, who was the model for Scott's antiquary" and also to Robert Burns, insofar as Mr. Ramsay epitomizes the problematic Victorian habit of romanticizing Scottish thinkers as emblems of a "genius," rebellious passion, and patriarchal wisdom that modern, rationalized Englishmen fear they lack ("Burns Night” 2013, 12-15; Hebrides 2013, 5152). From an archipelagic perspective, this would also mean that Mr. Ramsay is participating in a 
long tradition, best exemplified in Boswell's Journal of a Tour to the Hebrides with Samuel Johnson (beloved by Woolf), of casting the Celtic fringe as an emotive, atavistic antithesis to the rational pragmatism of "English" modernity. ${ }^{8}$

Another example of the novel's overt engagement with the contingencies of Scottish / English relationships is Charles Tansley, the young pupil of Mr. Ramsay who, more than any other of the family guests, is an advocate of Labour and a critic of imperial capitalism. Not coincidentally, Tansley traces his subversive political attitude to a lower middle class family history that is symbolized by an uncle, possibly Scottish, who "kept the light on some rock or other off the Scottish coast" (Woolf 1989, 92). While Mr. Ramsay and his guests are discussing more abstract matters, Tansley decries imperial policy in the Highlands by railing against the "wages and unemployment" and the government's "most scandalous acts" in the Hebrides, as well as the fact "that the fishing season was bad; that the men were emigrating" (93-94). When he boasts about his uncle the lighthouse-keeper, his listeners feel obliged to act with what could be called a typically Anglo-British attitude towards this image of the evanescent, masculineheroic Scottish laborer. As Woolf's narrator sarcastically implies, this well-rehearsed attitude is equal parts civil forbearance and patronizing romance: "They had to listen to him when he said that he had been with his uncle in a lighthouse in a storm" $(1989,92)$.

Tansley, whose voice is thoroughly filtered through others' consciousness and who apparently does not have Scottish family ties beyond his uncle, is benign at best as a voice of Scottish agency. His most viable defense of the region is arguably his dismissal of the romanticized image of Sir Walter Scott that others, chiefly Ramsay, uphold. His selfidentification with Scottishness does, however, help expose the dynamic of Britishness as a codependent crisis of identity and masculinity — one that leads equally to Mr. Ramsay's fear of lost 
passion and Tansley's insecure misogyny, the latter of which comes out in his famous proclamation that "women can't paint, women can't write" $(1989,48)$. Tansley is further linked with fringe subversion of Anglo-Protestantism via Guy Fawkes ("these mild cultivated people, who would be blown sky high ... one of these days by the gunpowder that was in him" [1989, 92]), but in a condescending way, and is arguably cast, or perceived by others, in the Scottish stereotype of a "talkative" agitator who is bullheadedly indifferent to social and class protocols $(1989,93)$. Woolf partly satirizes this dynamic, but also registers her own Anglocentric class position, when she writes that each person listening to Tansley worries that he or she ought to feel "outraged and indignant" at his facts, but really "feel[s] nothing at all [about] the government [and] the fishermen" $(1989,94)$.

The tensions and cultural postures surrounding Tansley thus serve as reminders that the modern anxieties inherent in the Ramsay family are those of late Britishness and not simply Englishness — of a milieu preoccupied with its imperial self-image, uncertain about its relationship to the Scottish periphery, and at its most vulnerable when its performative "civility" is exposed as such. The narrator's early nod to the decidedly British nature of the family's anxiety is thus strongly enhanced by the highland setting: "for there was in all their minds a mute questioning of deference and chivalry, of the Bank of England and the Indian Empire, of ringed fingers and lace, though to them all there was something in this of the essence of beauty" (1989, 7). It is worth noting that there are few better symbols of the Scottish roots of Great Britain than the Bank of England, given that its creation in 1694 essentially underwrote the Union of 1707 and its subsequent imperial ventures. But what is most important here is how Woolf implies that the simultaneous desire to fragment and retrieve constructs of Britishness- to "sport with infidel 
ideas" that "mute[ly] question" their hegemony while also sensing in them "the essence of beauty" (1989, 6-7) — is integral to each family member's flows of consciousness.

Indeed, it is in the novel's more subjective, aesthetic registers that its alternatively subversive and conservative attitude to Anglocentric Britain is most compellingly revealed. A central example is Woolf's impressionistic depiction of the Hebrides as a primal, synchronic zone that inherently resists the imperial concepts of historical progress and territorial dominion. Just as Woolf, in her diary, imagines her father's "discovery" of Talland House in St. Ives, Cornwall (the model for the fictional home in Skye) as a home on "the toenail of England" by a "glistening bay which he must have found as it was at the beginning of time" (qtd. in Lee 1999, 25), so too does To the Lighthouse attach "the awesome power of distance" to what it imagines as the primal aura of Skye's geography. ${ }^{9}$ In part, Woolf probably chose Skye over the source location of St. Ives because in the 1920's, with St. Ives immersed in tourism and second homes, Skye, where she had not yet been, represented for her the sense she once had, in Cornwall, of a foreign and primitive place at the very fringe of British space. That Woolf saw these primitive motifs as subversive of the present social order is suggested by the fact that the Ramsay daughters—who harbor "infidel ideas" against English feminine domesticity—are the most receptive to the anti-modern, disorienting forces of the island. Cam runs after "a vision ... of a fairy kingdom on the far side of the hedge" $(1989,54)$, Minta surveys the landscape "as if it were Constantinople seen through a mist" (73-74), and Nancy senses its "power sweeping savagely in ... reduc[ing] her own body, her own life, and the lives of all the people in the world, forever, to nothingness" $(1989,75-6)$.

The vision that allows Lily to complete her painting is similarly cast as a receptivity to the primal, synchronic energies of the land's end: 
Suddenly, as suddenly as a star slides in the sky, a reddish light seemed to burn in her mind .... It rose like a fire sent up in a token of some celebration by savages on a distant beach. She heard the roar and the crackle.... she loathed it. But for a sight, for a glory it surpassed everything in her experience, and burnt year after year like a signal fire on a desert island at the edge of the sea. $(1989,175)$

The suggestion here is that the "savage" island contains some universal desire—-perhaps the impulse to send "signals" and hence for culture to emerge from nature - that the artist channels as she seeks to give form to intersubjective experiences, essences "immune from change ... in the face of the flowing" $(1989,105)$. Such challenges to modern empiricism and historiographic linearity are consistent with what John Brannigan describes as the novel's subversion of the "geopolitical and patriarchal knowledge" disseminated in imperial, scientific discourses that "sought to gain mastery over nature," such as cartography, navigation, and meteorology (2015, 11-116). At another level, though, such equations of Skye with the synchronic, subjective, and primal also reflect reductive ideas of the Celtic fringe consistent with an Anglocentric cultural cartography. That is to say, even as it challenges imperial orders of history and place, Woolf's subjective impressionism also presupposes that the timeless essences and atavistic or universal forces which expose and threaten modernity are themselves inherent in and expressed by the Hebrides. These aesthetic maneuvers in turn obscure the materiality of Skye's own experiences of modernity, such as the land enclosures, mass emigrations, and "erosion and collapse of its native institutions" that marked its connection with the metropole and defined its turn of the century (Hobsbawm 1978, 308-9). The vaguely Celtic-Brittonic aura of such primitive-universal motifs, especially where, as in Lily's "savage" vision, they aim to counteract atomized modernity, reinstitutes a traditional, solipsistic practice whereby the metropolitan core seeks its 
obverse, as well as its presumed origin, in rural archipelagic zones that it consistently recasts as peripheral. Thus, even as To the Lighthouse disrupts imperial cartographies and delights in the notion of subjectivities drifting away and apart from hegemonic master discourses, so too do its themes of synchronic unity and retrieval re-appropriate Anglocentric cartographies and points of view.

This dynamic of fragmentation and retrieval, or this vacillation between wanting to dissolve and recover the construct of Britain, is especially evident in the novel's depictions of the relationship between land and water. Although Woolf did not visit the Hebrides until 1938, nor the West of Ireland until 1934, she knew enough from Cornish and English coasts that throughout the archipelago bodies of water and landmasses often appear to mingle along the horizon, challenging one's sense of their distinctness and hence of the terrestrial limit. This terraquatic effect, especially pronounced in the West of Ireland and Northwest Scotland, relates to the meaning of "archipelago" in Greek (the Greek word "archipelago" can be translated as a "great sea," or connective islands and water that assume the appearance thereof). In many instances, To the Lighthouse channels this topographical feature into habits of mind, equating water with modes of consciousness that disrupt territorial and nation-statist orientation. Lily Briscoe and William Bankes are drawn to the bay, for example, because "it was as if the water floated off and set sailing thoughts which had grown stagnant on dry land, and gave to their bodies even some sort of physical relief' $(1989,20)$.

However, as is often the case in Woolf's work, floating too far adrift from the connective fabric of the social body is also figured as risking engulfment in an utterly subjective, ambivalent, or universalizing fluidity of time and space. Lily Briscoe, for example, anxiously watches Mrs. Ramsay “drift into that strange no-man’s land where to follow people is 
impossible," and tries to follow her "as one follows a fading ship until the sails have sunk beneath the horizon" $(1989,84)$. When the habitual conversations around her stop, Mrs. Ramsay similarly moves from feeling in harmony with the cyclical crashing of surf to fearing the primal and universal arbitrariness of the sea: "like a ghostly roll of drums [the waves] remorselessly beat the measure of life, made one think of the destruction of the island and its engulfment in the sea" (1989, 15-16). Likewise, when the Ramsay home is left empty for years, its slow erosion is figured as an immersion: "sea-moistened" airs loosen its hinges $(1989,126)$, light through its panes gives the effect of "sun-lanced waters" $(1989,136)$, and it is nearly engulfed in "a pool of Time that was fast closing over them" $(1989,138 ; 139)$. In the same vein, Lily Briscoe, during a moment of socially detached, seaside contemplation, worries about being subsumed in "the waters of annihilation" $(1989,181)$.

Among their other functions, these figurative associations between social disassembly and the fluid, universalizing effects of aquatic submersion serve as an apprehensive critique of the integral land-water cartographies of imperial Britishness. After all, for any who would culturally identify with Great Britain, post-war modernity involved a threat to the centuries-old practice of imagining the sea as an extension of the nation and state, and of harnessing its universal nature to the cultural imaginary of Britishness. As recently as 1902, in his opus Britain and the British Seas, the English geographer Halford Mackinder had confidently apotheosized this practice by claiming that "Britain is possessed of two geographical qualities, complementary rather than antagonistic: insularity and universality." These were complementary, for Mackinder, because of England's control of "the ocean-highway, which is in its nature universal [as] every part of the ocean is accessible from every other part" $(1902,11)$. As John Hegglund has recently noted, Mackinder thus "imaginatively annex[es] the spaces of the ocean to the British empire" 
(2012, 112). As it vacillates between embracing the deterritorializing effects of the coast and using the unbounded sea as a metaphor for the alluring but lethal proposition of universality, $\underline{\text { To }}$ the Lighthouse offers a profoundly ambivalent meditation on the loss of this oceanic possession.

This ambivalence is especially evident in the "Time Passes" section, where universal time and space are closely aligned with water: the "downpouring of immense darkness" and "the flood, the profusion of darkness" that envelop the Ramsay home, for example, powerfully connect abstract time's erosion of particular memories and places with the dissolving and levelling properties of water $(1989,125-26)$. One of the more important associations between the aquatic and the synchronic occurs when Woolf compares the unruly waves to "leviathans" devoid of reason. For in doing so, she invokes the Hobbesian equation of leviathan and state and implies that the state, if not civil governance in general, have been lost to a primal, arbitrary force:

the winds and waves desported themselves like the amorphous bulks of leviathans whose brows are pierced by no light of reason, ... and lunged and plunged in the darkness or the daylight (for night and day, month and year ran shapelessly together) in idiot games until it seemed as if the universe were battling and tumbling, in brute confusion and wanton lust aimlessly by itself $(1989,134-35)$.

As "leviathan" regresses from state to beast, civil structure to "wanton" savage, so too are the cultural orders of particular time and space lost into a fluid "universe." The Ramsay home, threatened by time, is even figured as a ship "sinking, falling, [and about to] turn[] and pitch[] downwards to the depths of darkness" $(1989,138)$. Historical and linear units of time- “Night and day, month and year"- are subsumed "shapelessly" into an unmapped, synchronic statelessness in which, as Prue says, "one can hardly tell which is the sea and which is the land" 
$(1989,125)$. Thus, in the darkest moments of "Time Passes," we witness a complete reversal of British-imperial, terraquatic dominion. Yet we also witness an apprehensive, orientalist gesture of annihilation—one that harbors deep uncertainty about losing one's landed orientation and that relies, for its full aesthetic impact, upon an epistemological trajectory that had previously taken oceanic dominion for granted. The global purview of imperial Britain is, in other words, still inversely invoked by the capacious, liquid "oblivion" that would exist in its stead, as if there is no middle ground between an established historical-geographic dominion and an utterly fluid universe $(1989,139)$.

Similar anxieties over the prospect of post-imperial, devolved, decentered Britain are woven into the novel's intertextual conversation with earlier British literature, which often revolves around the theme of drowning. A prime example is Woolf's repeated allusion to William Cowper's 1799 poem "The Castaway," in which Cowper expresses his lifelong fears of isolation and transience through the figure of a sailor who has been thrown overboard from the ship of Commodore William Anson and left to drown in "the Atlantic billows." The poem begins by hailing the ship and its captain as embodiments of "Albion" ("No braver chief could Albion boast / . . / Nor ever ship left Albion's coast"), but concludes with the traumatic images of permanent isolation ("We perished, each alone") that echo in Woolf's novel (Cowper 1934, 43132). This combination not only underscores Woolf's concern that subjective dissociation from the connective tissues of society, taken to extremes, risks engulfment in seas of universal, indifferent space and time, but also indicates that she related this concern to the broader contingency of Great Britain. After all, it too is a drifting ship of state - in Cowper's words, a "floating home forever left" $(1934,431)$ —from which dissenting subjects both desire and fear to be cast adrift. 
The most telling of Woolf's allusions to Cowper is near the end of the novel when an older Cam, sailing to the lighthouse with her father and brother, looks back at Skye as it recedes on the sea's horizon. She first notices the island's perimeter and begins to see it as a geographic whole, its shape like a leaf "with a dent in the middle and two sharp crags" $(1989,188)$. As the island further recedes, it seems ever smaller, making "the sea more important now than the shore" $(1989,190)$. It could be said that To the Lighthouse similarly imagines the British island, inviting us first to think of its entire shape and perimeter, from St. Ives to Skye, then of its global smallness and vulnerability: "The island had grown so small that it . . looked like the top of a rock which some wave bigger than the rest would cover" $(1989,204) .{ }^{10}$ As she drifts away from the island, Cam tells herself a story of "adventure" about "escaping from a sinking ship" (1989, 188; 190). She concludes it, while "dabbling her fingers in the water," by thinking that here "a ship had sunk" and murmuring "how we perished, each alone" $(1989,191)$. The scene implies the need for an adventuresome "escape" from the familiar island but also, and crucially, the need to feel "safe" from drowning. The same combination is suggested when Cam only dangles her fingers in the water, a gesture that reiterates the fear of engulfment Mrs. Ramsay felt years ago when she had to reassure herself, regarding the family's journey to the lighthouse, that "they could not all be drowned" $(1989,79)$. In these moments, Woolf seems to recognize the paradox that the territory of belonging, however problematic, is also what allows cognitive subversions and peripheral, subjective adventures to exist. If we trust the meaning of terra firma, then our departures from it are titillating adventures; if not, then the land becomes watery and we are irreversibly submerged in rootlessness.

This dual allure and fear of submersion is also evident in Woolf's allusions to William Browne's "Siren's Song” (in particular, the lines “hither steer your winged pines / all beaten 
mariners") from the poet's 1613 Britannia's Pastorals $(1989,119)$. Compellingly, Browne's poem, an adaptation of Homer's sirens and a meditation on the enticing perils of adventure, deviates, as does Cowper's, from its author's more celebrated role as a landscape poet. As Woolf surely knew, Chambers Cyclopedia of English Literature, Kerrigan's icon of British cultural hegemony, praises Browne for his "vivid and true" descriptions of "the characteristic English landscape" (1880, 238-39) and lauds Cowper for showing readers "English scenery and domestic life faithfully and tenderly delineated" $(1902,602)$. That both poets were primarily known as charters of Anglocentric British space underscores the degree to which these poems reflect the drowning anxieties of the island nation; that is, not just the fact of British space being paradoxically defined and threatened by water, but also maritime Britain's idiosyncratically acute susceptibility to the fear that land, associated with established history and geography, might be lost to ungoverned water, associated with the "strange no man's land" of unstructured time and space $(1989,84)$.

Janet Winston has rightly observed that To the Lighthouse "stag[es] the decline of the British Empire through its obsessive attention to sinking ships and islands" $(1996,48)$. What I am additionally suggesting is that Woolf's aesthetic also links submersion with the concepts of historical and cultural synchronicity—or a subjective perspective that "confounds" and "confuses" objects — and that this linkage constitutes a far more ambivalent response to the potential dissolving or surrender of Britain $(1989,126 ; 128)$. In The Waves, which also evokes St. Ives and meditates on the coastal limits of Great Britain, Bernard repeatedly links submersion with universal sameness, such as when he worries about the aftermath of Percival's death in India: "how strange it seems to set against the whirling abysses of infinite space a little figure with a golden teapot on his head. ... Our English past—one inch of light. ... how can we do 
battle against this flood; what has permanence?" $(1978,227)$. In the dinner party scene just prior to "Time Passes," in To the Lighthouse, the narrator expresses a similar concern by contrasting the uniting customs of the family to the levelling flux of the external, fluid world. Gathering around their hostess, the family and guests view Skye's environment through "panes of glass, which, far from giving any accurate view of the outside world, rippled it so strangely that here, inside the room, seemed to be order and dry land; there, outside, a reflection in which things wavered and vanished, waterily." Once the group becomes "conscious of making a party together in a hollow, on an island" they also recognize "their common cause against that fluidity out there" $(1989,146-47)$. Importantly, what helps Woolf to trope Skye as "fluid" is, again, a subjective and de-materialized, touristic view of the Hebrides, insofar as the island landscape is associated not with modern historical events but with abstract or cyclical time. When Woolf finally visits Skye in 1938, her description of the island in a postcard to Duncan Grant reflects this same inclination to view the land as subjective, primitive, and fluid: "Skye is often raining, but also fine: hardly embodied; semi-transparent; . . . Remote as Samoa; deserted; prehistoric" $(1980,248){ }^{11}$

From an archipelagic perspective, these associations of the Hebrides with immaterial or non-objective states of being, and this tendency to use it as a conduit of entity-subsuming, oceanic liquidity, are all the more compelling because the Ramsay home on Skye is ultimately not absorbed by these forces. Rather, it is "rescued" from what the narrator describes as a fluid "universe" or "oblivion" via a poetical act of memory, retrieval, and reassembly $(1989,135$; 139). Indeed, the Scottish cleaning women's laborious restoration of the home, which is figured as the rescue of a capsizing ship $(1989,139)$, is a key manifestation of the novel's theme of connecting subjective experiences and hence saving individuals from "perish[ing] each alone" 
$(1989,135)$. The novel's aesthetic interest in reclaiming the fragments and peripheries of experience is thus compellingly parallel to its insistence on the act of reclaiming a Scottish territory. That is to say, what essentially happens in "Time Passes" is that a link between England and Scotland — or Britain in microcosm — is salvaged from a condition of utter, oceanic fluidity.

To elaborate on this key point, we might reconsider and further refine Jed Esty's influential argument about Woolf and the political cartographies of British Modernism in The

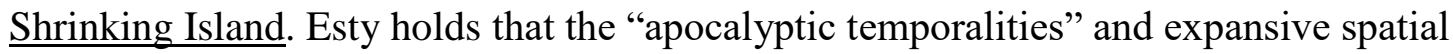
abstractions of British modernism are more typical of the early twentieth-century, with its emphasis on the aftermath of war $(2004,50)$, whereas the period of the 1930's to the 1960's is marked by an inward, "anthropological turn" $(2004,3)$ that "channel[ed] the potential energy of a contracting British civilization into a resurgent discourse" of native Englishness. T.S. Eliot's

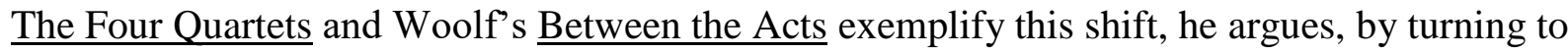
"the vitality of native rituals" and "natively English form[s] of primitive resistance to modernity" (2004, 55; 56; 64). To the Lighthouse, by contrast, with its concern for the "irreversible and disturbing aftereffects of a modern world war," falls more into the "apocalyptic" aesthetics of earlier English modernism $(2004,91)$. But if we look more closely at the cultural-geographic implications of the motifs of retrieval and reassembly in To the Lighthouse, we see more of what we would expect from a 1927 novel: a work poised at the very tipping point between post-war, imperial cataclysm and national retrenchment. Or, I would add, between imperial cataclysm and archipelagic reappraisal.

After all, Woolf's decision to take the biographical source material for To the Lighthouse - her childhood summers at Talland House in St. Ives, Cornwall, nearly the most 
southwestern point of Great Britain's Celtic fringe - and project it onto the Isle of Skye, one of the most northwesterly points of that fringe, is itself a form of archipelagic recovery or reappropriation (see fig 1). Just as the two halves of the novel divide and connect the pre-and postwar experiences of the Ramsay family, so too does Woolf's choice of setting, and her manner of internalizing it, conflate these two peripheries of the post-Irish United Kingdom. Indeed, this Cornish-Scottish superimposition becomes all the more significant when we note that Ireland is not only absent from the novel, but also impossible as an alternate setting. For despite the smaller island's ample selection of coastal settings that could signify in the same remote fashion, and that could inspire similar internalized reflection, Woolf would not have been as able to contain or control the meaning of Irish spaces, vis a vis Britishness, as she could with the Hebrides.

For one, this is because traditional, Anglocentric views of Scotland, which allowed Scottish difference to be cast in terms of romance, atavism, or mythology, still held sway, and were in fact essential to the dynamic concept of "Great Britain," whereas such views of Irish culture and society, although they certainly existed historically, had been too recently and violently challenged. Whereas Scotland's cultural nationalism had essentially helped strengthen the Union by being deferential to Britishness - supplying a romantic and mythic element that productively balanced the Scottish Enlightenment's capitalist and industrial leanings (Harvie 2008, 111-14) ${ }^{12}$ - Ireland's stronger and now more self-authored link between Celticism, Gaelic revival, and anti-imperial nationalism meant that such "ancient" mythologies, linked as they were to violent national assertion in the present, could not be so easily confined to a symbolic level. As John Nash has convincingly shown, the burdensome "Irish Question" was also so commonplace among Woolf's circle that she could not help but partake of its governing assumptions that the Irish "might be charming and even poetic, but [were] also incapable of self- 
control and political responsibility" $(2013,267)$. This decidedly colonial view of the Irish, Nash demonstrates, resonates throughout Woolf's essays and letters, where the Irish are persistently cast as inherently "wordy, overbearing, and ill-disciplined" (2013, 267-68).

Woolf did not visit Ireland until 1934, but her diary record of her time there-with Fianna Fáil republicanism on the rise and the Ascendancy "hating the Irish Free State" while clinging to what remained of their property under an evanescent Cumann na nGaedheal majority—reflects precisely these concerns $(1984,212)$. Although she loved Ireland's “great stretches of virgin seashore," notably remarking that they recalled "the original land that Cornwall \& much of England was in Elizabethan times," its landscapes struck her as too inscribed with historical material— "poverty, [emigration,] and a sense that life is receding"- to be thought of in such a remote, abstract manner $(1984,209)$. Concluding her trip in Dublin, Woolf writes of feeling "in the midst of history ... in an unsettled, feverish place," and concludes that "it wouldn't do, living in Ireland, in spite of the rocks and the desolate bays" $(1984,215 ; 216)$. Thus, unlike Skye, an Irish coast or periphery could not alternately serve her as a historically dematerialized signifier of "the original land" of the virgin British Isles and a conduit of subjectivity-inspiring, primal otherness.

That Woolf's aesthetic deployments of Scotland reflect a desire to retain or reassemble Anglocentric Britishness is also apparent in her allusions to Sir Walter Scott's Waverley novels. At one level, Woolf arguably uses Scott satirically, as a way to expose the links between the Victorian intelligentsia, patriarchal nostalgia, and romantic constructs of Scottishness. For example, during the male discussion of Voltaire and French history_-which takes an apparently familiar tack of praising Enlightenment rationalism, but also lamenting the difficulty of thinking beyond its eventually utilitarian manifestations-William Bankes praises the Waverley novels, 
proudly declaring that he reads two of them per year. Woolf's description of how Mrs. Ramsay only half-listens to this discussion implies that it amounts to a tired, phallic rite that predictably comes full circle once someone again starts romancing the faded Gael:

she let it uphold her and sustain her, this admirable fabric of the masculine intelligence, which ran up and down, crossed this way and that, like iron girders spanning the swaying fabric, upholding the world, so that she could trust herself to it utterly, even shut her eyes, or flicker them for a moment .... Then she woke up. It was still being fabricated. William Bankes was praising the Waverley novels. $(1989,106)$ Tansley argues that no one reads Scott anymore, a comment that Mrs. Ramsay fears will undo the weary, but class-sustaining habit of discussion because it will make Mr. Ramsay worry about his own fading reputation. Mrs. Ramsay's concerns are justified when Mr. Ramsay, threatened by his evanescent scholarly reputation, takes to reading the Waverley novels. Selfishly, however, he derives from them an "astonishing delight and feeling of vigour" that renews his own feelings of worth and his devotion to Carlyle, Hume, and the rational empiricists $(1989,120)$.

Arguably, this subplot of a Scott-inspired, Jacobite-romantic renewal of male, rationalist intellect is a subtle satire of the larger scale drama in which English hegemony must repeatedly construct the image of an intemperate Scottish fringe whose passions can be lionized, but only in retrospect, as part of the progress toward a civil and empirical British state. Indeed, this was largely the purpose Scott himself saw Waverley, and its stirring flirtations with the Jacobite cause and Highland culture, as serving in 1814. Comparing his work to Maria Edgeworth's Castle Rackrent (1800), which the author hoped would justify the impulsive Irish to English audiences and thus strengthen the new Union $(1992,63)$, Scott suggests in his 1829 preface that the Waverley series might similarly "introduce [Scottish] natives to [our] sister kingdom in a 
more favorable light than they had been placed hitherto, and . . procure sympathy for their virtues and indulgence for their foibles" $(1985,523) .{ }^{13}$ One of the strongest strains of modern belatedness in To the Lighthouse is the fact that the Ramsay group still engage in this threadbare, self-serving practice of inscribing Scottish difference in the past tense, coding it as spiritually elemental but impractical and hence historically concluded. Woolf is thus exposing and critiquing this Anglocentric practice, as is evident in the novel's conclusion when "the little tinge of Scottish accent" returns to Mr. Ramsay's voice, "making him seem like a peasant himself" while Macalister takes him out to the lighthouse with James and Cam (1989, 164).

Yet even as she satirizes such time-worn appropriations of Scottish identity, so too does her novel perpetuate them. For one, even if Woolf's intent is to expose the vulnerable Anglocentrism of the Ramsay group, readers are not permitted outside the luminous halo of their subjective view of the archipelago. Thus, the debate over whether Sir Walter Scott is valuable follows a relatively typical pattern in modernist allusions: the literary past that is up for debatethat is to be either sundered or retrieved, censured or praised - is itself a limited cultural field that reflects a dominant and canonical ideology. The Waverley novels are of a piece with the allusions to Cowper, Browne, Tennyson, Shakespeare, Carlyle and others in that they testify to the Anglocentric range or scope within which questions of meaning (what has modernity torn asunder? From its aftermath, what can be salvaged?) are being posed. This limited, conservative range regarding Scottish texts in the British canon parallels Woolf's own range of vision as a critic, which substantively included older, classical authors like Scott and Burns but censured more subversive voices like Robert Louis Stevenson and barely recognized the then contemporary Scottish renaissance. The counter to such hegemonic readings of Scottish literature is represented by Tansley's argument that Scott is irrelevant to the current political moment, but 
he is not intended to be taken seriously. Indeed, as in Woolf's own critical essays on Scott, the novel's overall attitude towards the Waverley series is thus conservatively twofold: although it signifies an archaic, patriarchal romanticism, it also embodies presumably "universal" premodern and anti-modern sentiments that must be salvaged. A subtle, if unintended, effect of this gesture is that of recovering or reigning in a potentially divergent Scottish culture.

This problematic rationale is dramatized when the Waverley novels are "fetch[ed] up from oblivion [with] a tea set one morning" by the pair of Scottish cleaning women $(1989,139)$. The retrieval of these two decidedly British icons may be partly satirical, but it also conveys, in equal measure, a genuine anxiety at the prospect of losing an Anglocentric cultural hegemony of the Isles. After all, the novels are rescued from the fluid darkness of time by women who are in many ways canonical caricatures of the Scottish working class: "the toothless, bonneted" Mrs. McNab and her companion Mrs. Bast, "red-haired [and] quick-tempered like all her sort" (1989, 130;139). To be sure, Mrs. McNab is increasingly humanized and treated with compassion as she restores the property. However, as a symbol of "witlessness, humour, [and] persistency itself" $(1989,130)$ —a class-bound embodiment of universal long suffering, "incorrigible hope," and "a force working [to restore]; something not highly conscious" $(1989,131 ; 139)$ —she also reflects a lot of what Woolf patronizingly lauded in Scott's characters: a tidal force of humanity that, like nature itself, cyclically creates or destroys while remaining indifferent to modern social structures. Mrs. McNab thus arguably embodies the broader, dual, Anglocentric image of Scotland with which we are concerned: a conduit of primal, modernity-resisting forces that is nonetheless also controlled, put to the service of sustaining or reviving the dominant English point of view. 
Woolf, who was herself an admirer and voracious reader of Sir Walter Scott, after all shares many of William Bankes's and Mr. Ramsay's romantic and canonical sentiments about the power of the novelist's capacious and verbally unconstrained rendering of humanity. Indeed, Mr. Ramsay's therapeutic reaction to the scenes of "poor Steenie's drowning, and Muclebackit's sorrow" is essentially Woolf's own $(1989,120)$. In her retrospective essay on Scott's The Antiquary, the third novel in the Waverley series, for The New Republic in 1924, Woolf in fact connects her emotions when reading Scott to a restorative, near-lethal submersion. Setting out to defend a then-popular "Waverley novel reading habit," Woolf admits a certain lack of sophistication in Scott, but goes on to celebrate the manner in which his works forsake "the languor of the fine gentlemen who bored him" while advancing "the immense vivacity of the common people whom he loved" $(1986,455)$. For Woolf, the natural, organic force of his characters, "ladies and gentlemen ... scarcely to be distinguished from 'the winged denizens of the crag" who surround them, amounts to a tidal wave of "perennial vitality" that carries away the reader, drowning all pretense of "proper," class-sanctioned morality and aesthetic taste $(1986,456)$.

Woolf repeatedly compares Scott's narrative scope and "talkative" characters to an ungovernable sea, a metaphor that combines her characterization of lower class "talk" as a primal force (such as Mrs. McNab's ability to "drink and gossip as before" $[1989,131])$ with her motif of the order-negating universality of the sea. This figuring of Scott's Highlanders as oceanic — as a threatening yet ultimately restorative tide of indifference to structured society —is arguably the ultimate gesture of containment. Woolf praises "the deep, the inscrutable, the universal ocean" that is Scott's "complete presentation of life," and hails the storm-tossed manner in which "the parts [of his fictional world] grew together without his willing it, and 
broke into ruin again without his caring" $(1986,457)$. She cites his depiction of a violent northern sea, which in Scott's words “"clouds like disasters around a sinking empire,"” as emblematic of this effect, and lauds the way in which such ornate descriptions are suited to the cultural indifference of a highland storm that "roars and splashes and almost devours the group huddled on the crag" $(1986,454)$. As she elaborates this feeling of being "almost devour[ed]" by Scott's oceanic prose, one senses her already thinking of the near-lethal engulfment of the Ramsay home in To the Lighthouse. "The result [of Scott's writing] is strange," she writes, for it reminds one that "the sovereigns who should preside have abdicated, [and] we are afloat on a broad and breezy sea without a pilot" $(1986,457)$. Woolf thus sees in Scott's narratives one of the core images of her own gestating novel: the forces of nature subsuming particular human endeavor and territory, or rather almost subsuming these entities, into a lethal and watery cosmos, leaving in their wake a vision of something ungovernably universal, of a unity between things.

To achieve her full effect in To the Lighthouse, Woolf thus needs the Scottish highlands to function much like she feels that they do in the Waverley novels: as both a conduit of the universal, liquid force of primal indifference and a physical, familiar place that is so essential to the construction of one's own society that it must be continually retrieved. In The Islands of Scotland (1939), Hugh MacDiarmid would later criticize precisely this practice whereby the romantic image of the Highlands shifts into the modernist era's desired image of anti-modern, universalizing primitivism. Challenging the deployment of such dematerialized images of the Hebrides that serve “civilization's urgent need today to refresh and replenish itself at its original sources," MacDiarmid chides that "it is precisely the chief characteristic of the [island region] that if its history could be fully recovered, the very basis of our conceptions of British history 
would have to be torpedoed and very different conceptions take their place" (1939, ix). A sinking and shrinking imperial archipelago, that is to say, only appears as such, and only appears as a crisis, from within an Anglocentric construction of archipelagic time and space.

"People soon drift apart," Mr. Bankes thinks to himself. Indeed, there is something uncannily archipelagic in To The Lighthouse's pervasive theme of drifting, separating bodies. Evan as the novel poetically explores the distance of each individual consciousness from another, alongside the increased sense of "disintegration" in the wake of personal and national tragedies, so too is it based in the longing to unify — to "summon[] together," or to "str[i]k[e] everything into stability" (1989, 112; 62; 113). Throughout it runs the desire, as Lily muses, to form "one stream" out of "she ... and this, and this . . the sofa on the landing (her mother's); . . the rocking chair (her father's); . . the map of the Hebrides" in the hope that they might be "revived again" (1989, 113-14), or "illumined [from] the darkness of the past" $(1989,172)$. As such, $\underline{\text { To }}$ the Lighthouse registers a crucial moment in the idea of Britain. On the one hand, it subversively deploys the Hebrides as a fringe space whose diffuse, fractile coasts expose the contingent vulnerability of "Great Britain" as a cultural-geographic abstraction. On the other, instead of linking Scotland with concrete alternatives to that abstraction, it associates the islands with a universalizing, all-subsuming synchronicity into which subjects might be perennially cast adrift but for their desire to reconnect. In doing so, the novel quite literally "retrieves" or redeploys English-metropolitan constructs of the Scottish periphery as an historically discontinuous and immaterial space - a place of romance, atavism, and the folk-universal. The result is a critical, yet decidedly Anglocentric, image of 1920's Britain in the wake of Irish independence: a shifting, contingent space shoring its imperiled substance against an arbitrary, watery universe. 


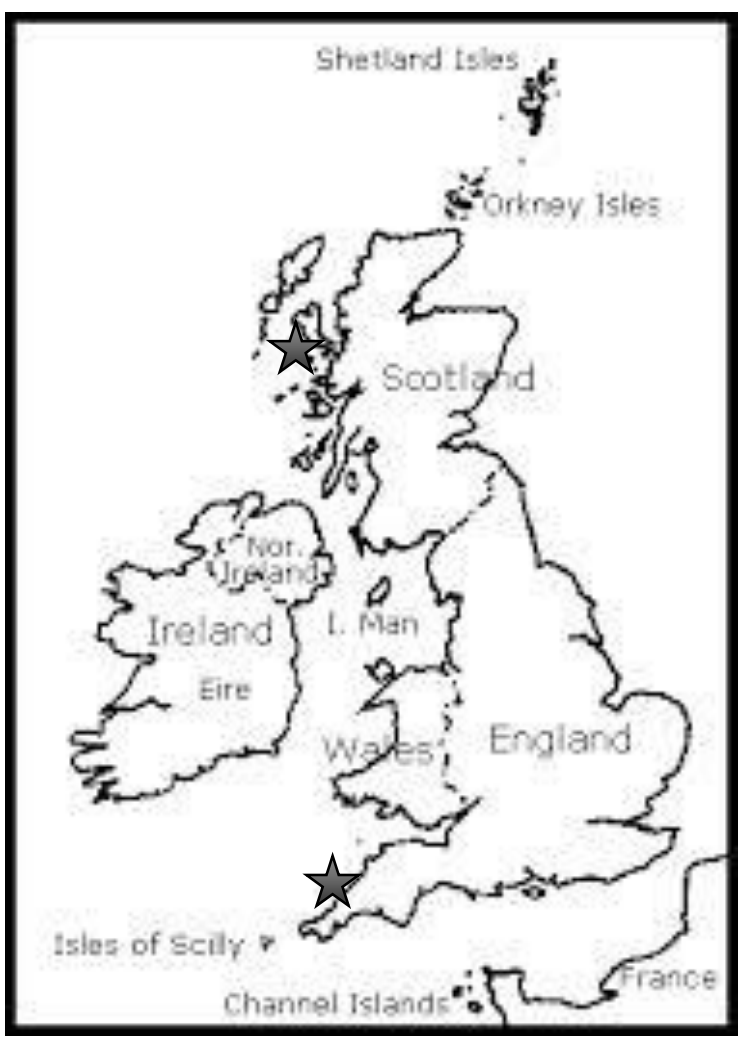

Fig 1: The Isle of Skye and St. Ives 
Works Cited

Allen, Nicholas. 2011. Modernism, Ireland and Civil War. Cambridge: Cambridge University Press.

Arnold, Matthew. 1883. On the Study of Celtic Literatures and On Translating Homer. New York: MacMillan.

Browne, William. 1919. “The Siren's Song.” In The Oxford book of English verse, 1250-1900, edited by A.T. Quiller-Couch. Oxford: Clarendon.

Beer, Gillian. 2013. "The Island and the Aeroplane: The Case of Virginia Woolf." In Nation and Narration, edited by Homi K. Bhabha, 255-290. Florence: Taylor and Francis.

Brannigan, John. 2015. Archipelagic Modernism. Edinburgh: University of Edinburgh Press.

Chambers, Robert, editor. 1880. Chambers's Cyclopaedia of English Literature, A History, Critical and Biographical, of British and American Authors, with Specimens of Their Writings, volume 1. New York: American Book Exchange.

---. 1902. Chambers's Cyclopaedia of English Literature, A History, Critical and Biographical, of British and American Authors, with Specimens of Their Writings, volume 2. Edinburgh: W. \& R. Chambers.

Colley, Linda. 2005. Britons: Forging the Nation, 1707-1837. New Haven: Yale University Press.

Cowper, William. 1934. "The Castaway.” In The Poetical Works of William Cowper, $4^{\text {th }}$ edition, edited by H.S. Milford, 431-32. 
Deane, Seamus. 1987. "Masked with Matthew Arnold's Face: Joyce and Liberalism.” In James Joyce: The Centennial Symposium, edited by Morris Beja, et. al, 9-20. Chicago: University of Illinois Press.

Devine, T.M. 2003. Scotland's Empire: 1600-1815. London: Allen Lane.

During, Simon. 1992. "Waiting for the Post: Some Relations Between Modernity, Colonization, and Writing." In Past the Last Post: Theorizing Post-Colonialism and Post-Modernism, edited by Ian Adam and Helen Tiffin, 23-47. Calgary: University of Calgary Press, 1990.

Edgeworth, Maria. 1992. Castle Rackrent and Ennui. New York: Penguin.

Esty, Jed. 2004. A Shrinking Island: Modernism and National Culture in England. Princeton: Princeton University Press.

Fleet, Christopher, Margaret Wilkes, and Charles W. J. Withers. 2011. Scotland: Mapping the Nation. Edinburgh: Birlinn.

Goldman, Jane. 2013. Burns Night/Woolf Supper: Birthday Thoughts on Virginia Woolf and Scotland. Annual Virginia Woolf Birthday Lectures (series). Fairhaven: Virginia Woolf Society of Great Britain.

---. 1992. "Metaphor and place in To the Lighthouse: some Hebridean connections." In Tea and Leg-Irons: New Feminist Readings from Scotland, edited by Caroline Gonda, 137-155. London: Open Letters.

---. 2014. "Two Postcards from Skye: Virginia Woolf in the Hebrides." Virginia Woolf Miscellany no. 85 (2014): 13+.

---. 2013. 'With You in the Hebrides': Virginia Woolf and Scotland. London: Cecil Woolf. Harvie, Christopher. 2008. A Floating Commonwealth: Politics, Culture and Technology on Britain's Atlantic Coast, 1860-1930. Oxford: Oxford University Press. 
---. 2004. Scotland and Nationalism. New York: Routledge.

Hegglund, John. 2012. World Views: Metageographies of Modernist Fiction. Oxford: Oxford University Press.

Hobsbawm, E.J. 1878. Industry and Empire. New York: Penguin.

Kerrigan, John. 2008. Archipelagic English: Literature, History, and Politics, 1603-1707. Oxford: Oxford University Press.

Lee, Hermione. 1999. Virginia Woolf. New York: Vintage.

Lincoln, Andrew. 2007. Walter Scott and Modernity. Edinburgh: Edinburgh University Press.

MacDiarmid, Hugh. 1939. The Islands of Scotland: Hebrides, Orkneys, and Shetlands. New York: Scribner's.

Mackinder, Halford. 1902. Britain and the British Seas. New York: D Appleton and Company. Nash, John. 2013. “'talk \& talk \& talk': Virginia Woolf's Responses to Ireland.” Irish Studies Review 21 (3): 255-73.

Phillips, Kathy. 1994. Woolf Against Empire. Knoxville: U of Tennessee Press.

Pocock, J.G.A. 2005. The Discovery of Islands: Essays in British History. Cambridge: Cambridge University Press.

Scott, Walter. 1985. Waverley. New York: Penguin.

Winston, Janet. 1996. "Something out of Harmony: To the Lighthouse and the Subject(s) of Empire." Woolf Studies Annual 2, 39-70.

Woolf, Virginia.1986. “The Antiquary.” In The Essays of Virginia Woolf, Volume 3: 1919-1924, edited by Andrew McNeillie, 454-458. New York: Harcourt.

---. 1984. The Diary of Virginia Woolf, Volume 4, edited by Anne Olivier Bell. New York: Harcourt. 
---. 1980. The Letters of Virginia Woolf, Volume 6: 1936-1941, edited by Nigel Nicolson and Joanne Trautmann. New York: Harcourt.

---. 1994. The Essays of Virginia Woolf, Volume 4: 1925-1928, edited by Andrew McNeillie. New York: Harcourt.

--- 1985. Moments of Being, edited by Jeanne Schulkind. New York: Harcourt.

---. 1989. To the Lighthouse. New York: Harcourt.

--- 1978. The Waves. New York: Harcourt.

Zumkhawala-Cook, R. 2008. “Tae the Lichthoose.” In Virginia Woolf: Art, Education, and Internationalism; Selected Papers from the Seventeenth Annual Conference on Virginia Woolf, edited by Diana Royer and Madelyn Detloff, 57-63. Clemson, SC: Clemson University Digital Press. http://tigerprints.clemson.edu/cgi/viewcontent.cgi?article=1005\&context=cudp_woolfe 
${ }^{1}$ For example, the work of Nicholas Allen and John Brannigan, in Modernism, Ireland, and Civil War (Cambridge University Press, 2012) and Archipelagic Modernism (Edinburgh University Press, 2015), respectively, as well as the ongoing work of the Atlantic Archipelagos Research Consortium.

${ }^{2}$ Goldman has demonstrated, for example, the correlation between Woolf's use of a Scottish setting and her critique of patriarchy: "The ruling English patriarchy mythologized and allegorized Scotland into subservience" just as it did to women via the institution of marriage, hence "Woolf"s Hebridean setting is perfect for a novel seeking to explore and dismantle the values of the old order" $(1992,146)$. She has also convincingly demonstrated that Woolf was for much of her life "a keen mental traveler to Scotland" and that her many allusions to Scottish literary and political romance are key to the novel's own rebellious sensibilities $(2013,8 ; 23-32)$.

${ }^{3}$ In "Tae the Lichthoose: Woolf"s Scotland and the Problem of the Local," Richard Zumkhawala-Cook proposes that "Scotland functions as an effort to disrupt the stability of nation altogether," helping the novel to "resist[] national identifications so as to highlight alternative solidarities, namely the material conditions of gender and class represented throughout the text" (2008, 57-58). Additionally, several pioneering studies of Woolf and empire pay only passing attention to the Scottish setting. Janet Winston notably reads the novel as an "imperial allegory" wherein "tropes of imperialism" are ironically juxtaposed to reveal the "conflicting ideologies" of the colonial enterprise (1996, 162). In Woolf Against Empire (1994), Kathy Phillips also offers a thorough analysis of Woolf's critique of the interrelationships of gender and imperialism in the novel. Neither consider that Scotland itself functions as a colonial setting.

${ }^{4}$ As Hugh MacDiarmid puts it in The Islands of Scotland, the Hebrides "resemble very much a many roomed house [in which] entirely different activities are going forward," and of which "a general assembly ... is unthinkable" due to their distinct local contours and varied maritime connections to other locations $(1939,7)$.

${ }^{5}$ According to Hermione Lee's biography of Woolf (1999, 471-72).

${ }^{6}$ As Seamus Deane puts it, Arnold's Celt is "merely a term in an argument which has as its goal the ratification of the great project for a ... perfectly irresistible English civilization" - an appeal to "save morality by making his audience nostalgic for it rather than eager practitioners of it," where "nostalgia is properly given to something already lost" (1987, 13-14).

${ }^{7}$ Woolf writes to her cousin Emma Vaughan in 1907: "my Scotch blood had mixed long ago with the French and English, so that the finest connoisseur tasting it can detect only a peculiar sweetness . . . like the essence or soul of something long since dead" (qtd. in Goldman, 2013, 8).

${ }^{8}$ As Simon During notes of Boswell and Johnson's 1775 Journey to the Western Islands, both the act and the style of English writing about the Hebrides has typically taken the place of an otherwise fluid boundary between the two societies. While the Scottish north is transformed, as it is written about, into a collective signifier of an indigenous pre-modern society, the status of the writer/observer as existing in a mobile frame of reference known by contrast as "modern" and rational is affirmed and strengthened by the same process (1990, 24-5).

${ }^{9}$ The Stephen family purchase of Talland House is a prime example of the spread of modernization into the Celtic fringe. As Woolf notes in "A Sketch of the Past," the home was purchased in 1877, "the first year ... that the line from St. Erth to St. Ives was open" $(1985,26)$. In the tourism and vacation home boom of the last decades of the $19^{\text {th }}$ century, urbanites of means began to secure summer homes on the coastal edges and islands of Great Britain, bringing tourist economies that paralleled and often augmented the decline of local industries. 
${ }^{10}$ As Gillian Beer (2013) observes, To the Lighthouse reflects an increasing aerial awareness of the perimeters of England and Britain as islands that are relatively small in contrast to their imagined imperial dominion and scope: "To the Lighthouse is Woolf's island story. The family group and the house itself are themselves contracted intensifications of the island concept [as is] the final separation of the individual each from each" (272).

${ }^{11}$ As Jane Goldman observes, Woolf's postcard equates Skye with a "primal existentialism" that sounds a lot like her famous metaphor of consciousness as "a luminous halo, a semi-transparent envelope surrounding us" (2014,

13) (Woolf quotation from "Modern Fiction," Essays vol. 4, 1994).

${ }^{12}$ In A Floating Commonwealth, Christopher Harvie (2008) maintains that the idea of "Great Britain" depended on a dynamic linkage between the metropolitan core and its arc of industrial, coastal cities and their hinterlands. The key to this linkage of diverse economies and cultures was "a Scots intellect which refereed the dialectic between the rationality of the enlightenment and the emotional impulse towards the old order: appealing to conservatives as well as to progressives and secularists" (112). This double appeal included "a cultural recognition of Scotland which [unlike Irish cultural nationalism] balanced its political integration with England" (113).

${ }^{13}$ As Andrew Lincoln (2007) puts it in Walter Scott and Modernity, Scott's aim with regard to Highlanders and Jacobites was "to represent and contain" them within an inevitable trajectory of the increasingly rational nation-state (2): "By representing political and social conflict within the larger context of the progress of society, Scott could undermine arguments for radical change, and encourage acquiescence in the status quo. Scott's progressive vision of history is always in the service of a conservative vision of moderation" that was in turn key to the development of the modern British state (6). 